\title{
Pemahaman Aplikasi E-Bekal bagi Wali Asuh Santri sebagai Upaya Pencegahan Penyalahgunaan Uang Belanja Santri di Pesantren
}

\author{
Nadiyah$^{1}$, M. Syafiih2, Deviana Dianita ${ }^{3}$, Musrifatul Arifah ${ }^{4}$, Murliatus \\ Saniyah $^{5}$, Siti Qurrotul Fu'adi ${ }^{6}$, Titin Agustin 7 , Virda Virdausih Putri ${ }^{8}$, \\ Nurul Hidayati ${ }^{9}$ \\ Universitas Nurul Jadid, Probolinggo $1,2,3,4,5,6,7,8,9$ \\ \{nadiyah@unuja.ac.id ${ }^{1}$, m.syafii01@gmail.com², devianadianita3105@gmail.com³ \\ musrifatularifahifah@gmail.com ${ }^{4}$, murlyatus@gmail.com ${ }^{5}$, uungfuadi@gmail.com ${ }^{6}$, \\ titinagustin996@gmail.com ${ }^{7}$, virdavirdausiahputri@gmail.com ${ }^{8}$, \\ nurulhidayatinashoruddin@gmail.com $\left.{ }^{9}\right\}$
}

Keywords:
Boarding School,
Application,
Management,
Provision,

Shopping

\begin{abstract}
E-Bekal is a shopping application for students at the Nurul Jadid Paiton Probolinggo Islamic Boarding School, the idea of making the application is to provide solutions to problems experienced by the Islamic boarding school. These problems include (1) the santri's spending money is not controlled by the management, there is an imbalance in the santri's spending money coming from an economy that is capable of spending a lot of spending. Conditions like this will create social jealousy for other santri, the management immediately responds to this condition because some observations and evaluation results from the results of cases that occur there are some santris who will be affected by the lifestyle of students whose economies are related to students with weak economies. (2) There are frequent cases of losing money in provisions for santri. Based on the results of the evaluation of the management every month, cases of losing money from santri can occur every day. (3) can regulate santri spending money with pesantren policies. (4) parents can control and evaluate santri spending money, santri guardians can also TOPUP (send) money online using an application according to the bank specified by the pesantren. (5) pesantren administrators conduct socialization and training on the use of the E_BEKAL application as provisions for students' understanding of the use of the E_BEKAL application.
\end{abstract}

Katakunci: Abstrak. E-Bekal merupakan Aplikasi belanja santri Pondok Pesantren Nurul Jadid Paiton Probolinggo, ide pemikiran Pesantren, dibuatkannya aplikasi tersebut untuk memberikan solusi atas Aplikasi, $\quad$ permasalahan yang dialami oleh pondok pesantren. Permasalahn 
Management, tersebut meliputi (1) uang belanja santri tidak terkontrol oleh Bekal, Belanja pengurus adanya ketimpangan uang belanja santri yang berasal dari ekonomi yang berkecupan akan menghabiskan belanja yang banyak. Kondisi seperti ini akan menimbuilkan kecemburuan sosal bagi santri yang lain, pengurus segera menyikapi kondisi seperti ini karena beberapa pengamatan dan hasil evaluasi dari hasil kasus yang terjadi ada beberapa santri akan terpengaruh dengan pola hidup santri yang ekonominya berkecupan terhadap santri yang ekonominya yang lemah. (2) Sering terjadinya kasus kehilangan uang bekal santri, berdasarkan hasil evaluasi pengurus setiap bulan, kasus kehilangan uang bekal santri bisa terjadi setiap hari. (3) bisa mengatur uang belanja santri dengan kebijakan pesantren. (4) orang tua bisa mengontrol serta evaluasi uang belanja santri, wali santri juga bisa TOPUP (kirim) uang secara online menggunakan aplikasi sesuai bank yang telah ditentukan oleh pesantren. (5) pengurus pesantren melakukan sosialisasi dan pelatihan penggunaan aplikasi E_BEKAL sebagai bekal untuk pemahaman santri terhadap penggunaan aplikasi E_BEKAL.

\section{Pendahuluan}

Pondok Pesantren Nurul Jadid Paiton Probolinggo merupakan lembaga pendidikan pesantren yang didirikan oleh almarhum KH. Zaini Mun'im pada tahun 1948 M dengan menerapkan sistem modern. Pesantren terbesar setapal kuda ini nampaknya mendapat pengakuan yang cukup luas dikalangan masyarakat. Terbukti dengan makin banyaknya jumlah santri yang berdatangan dari segala penjuru tanah air, bahkan dari luar negeri (Singapura dan Malaysia). Karena banyaknnya santri dari berbagai waliyah dan latar belakang yang berbeda sehingga pesantren membutuhkan aplikasi untuk menampung berbagai transaksi keuangan santri secara efisien sehingga mucul gagasan E-Bekal sebagai aplikasi mobile untuk mempermudah wali santri Pondok Pesantren Nurul Jadid dalam melakukan pembayaran kos makan santri, pengiriman bekal belanja harian santri, sehingga santri langsung dapat melakukan transaksi secara non tunai di area Pondok Pesantren Nurul Jadid. 
Karena Indonesia merupakan salah satu Negara yang terdampak pandemi Covid-19, hal ini menyebabkan banyak terganggunya berbagai aspek kehidupan baik dalam bidang pendidikan, ekonomi dan budaya. Salah satunya dalam bidang pelayanan kepesantrenan yang kita semua ketahui salama ini didalam pesantren sendiri hampir 70\% pelayanan masih menggunakan off line atau manual. Sebelum pandemi banyak wali santri yang rutin mengunjungi santri untuk berbagai keperluan dan tentunya untuk memberikan bekal santri. Mengingat jumlah pasien terpapar covid $19 \mathrm{di}$ Indonesia terus menaik akhirnya pemerintah memberikan banyak peraturan dan himbauan untuk memutus mata rantai penyebaran covid 19 ini salah satunya untuk "Stay at Home", dan mengurangi kerumunan. Maka untuk itu sejak Awal kembali santri lama pada bulan Juli 2020, biro pengembangan, kepesantrenan, dan keuangan pesantren melakukan pertemuan untuk menyikapi bekal santri ditengah pandemi ini yang banyak mengalami keterbatasan akses ke pesantren secara langsung sehingga hasil dari pertemuan itu dirumuskanlah suatu sistem yang mengakomodir wali santri dalam melakukan pengiriman bekal berupa uang yang dapat dilakukan dengan mudah dimana saja dan kapan saja.

Sejarah E-Bekal merupakan dari salah satu program Simpanan Santri (SS) yang mengangi secara langsung simpanan keuangan santri meliputi uang saku, uang bekal belaja dan kebutuhan selama berada di pondok pesantren. Santri dapat melakukan aktifitas keuangan melalui Simpanan Santri (SS), program ini diterapkan untuk memenuhi kebutuhan santri untuk mengelola keuangan. Pada bulan Juli 2020 Simpanan Santri berubah menjadi Simpanan Bekal Santri (SBS) inilah cikal bakal berdirinya E-Bekal yang berbasis Aplikasi. E- Bekal ini bisa digunakan santri diseluruh koperasi (kantin) pondok pesantren Nurul Jadid. Masalah yang sering muncul ialah kehilangan uang santri dan penyalahgunaan uang kiriman santri yang tidak dipakai sebagaimana mesktinya.

Solusi untuk menyelesaikan masalah tersebut Pondok Pesantren Nurul Jadid membuat strategi baru, yaitu dengan meluncurkan suatu sistem yang disebut E - Bekal dengan E-Bekal diharapkan semua transaksi di pondok pesantren Nurul Jadid berbasis Cashless. Dengan strategi ini, berbagai masalah pesantren Nurul Jadid sedikit demi sedikit teratasi dengan baik, santri dapat hidup lebih hemat dan meminimalisir adanya kehilangan uang juga timpang tindih uang belanja antar santri, pengurus dan wali santri juga 
mudah mengotrol arus keuangan santri dengan valid dan efisien, dan berbagai unit usaha dalam pesantren pun mengalami kemajuan yang cukup signifikan.

E-Bekal menjadi bahan evaluasi dan monitoring oleh pengurus, pengasuh dan wali santri. E-Bekal menjadi alat transaksi yang praktis dan efisien serta membatasi belanja santri setiap hari, orang tua dapat melakukan transaksi (pengiriman) uang bekal santri secara online dan mendapatkan notifikasi pengeluaran santri setiap saat. Aplikasi E-Bekal hanya bisa digunakan (transaksi) di wilayah pondok pesantren Nurul Jadid. Tujuan pengembangan kedepan E-Bekal bisa digunakan untuk transaksi E-Tol, penarikan uang dan transfer.

\section{Metode}

Pelaksanaan program pengabdian ini ditujukan untuk seluruh santri, pengurus dan wali santri Pondok Pesantren Nurul Jadid. Sebanyak 30 peserta yang mengikuti pelatihan terdiri dari santri wilayah Al-Hasimiyah dan Wilayah Barat Pesantren Nurul Jadid. Dengan tetap menerapkan protokol kesehatan, pelaksanaan pengabdian kepada masyarakat ini berlangsung pada Senin, 03 Maret 2021 dari jam 09.00 WIB - 12.00 WIB yang bertempat di Aula Mini Unuja dengan tema Pelatihan Aplikasi E-Bekal bagi Wali Asuh Santri PP. Nurul Jadid sebagai Upaya Pencegahan Penyalahgunaan Uang Belanja Santri di Pesantren. 


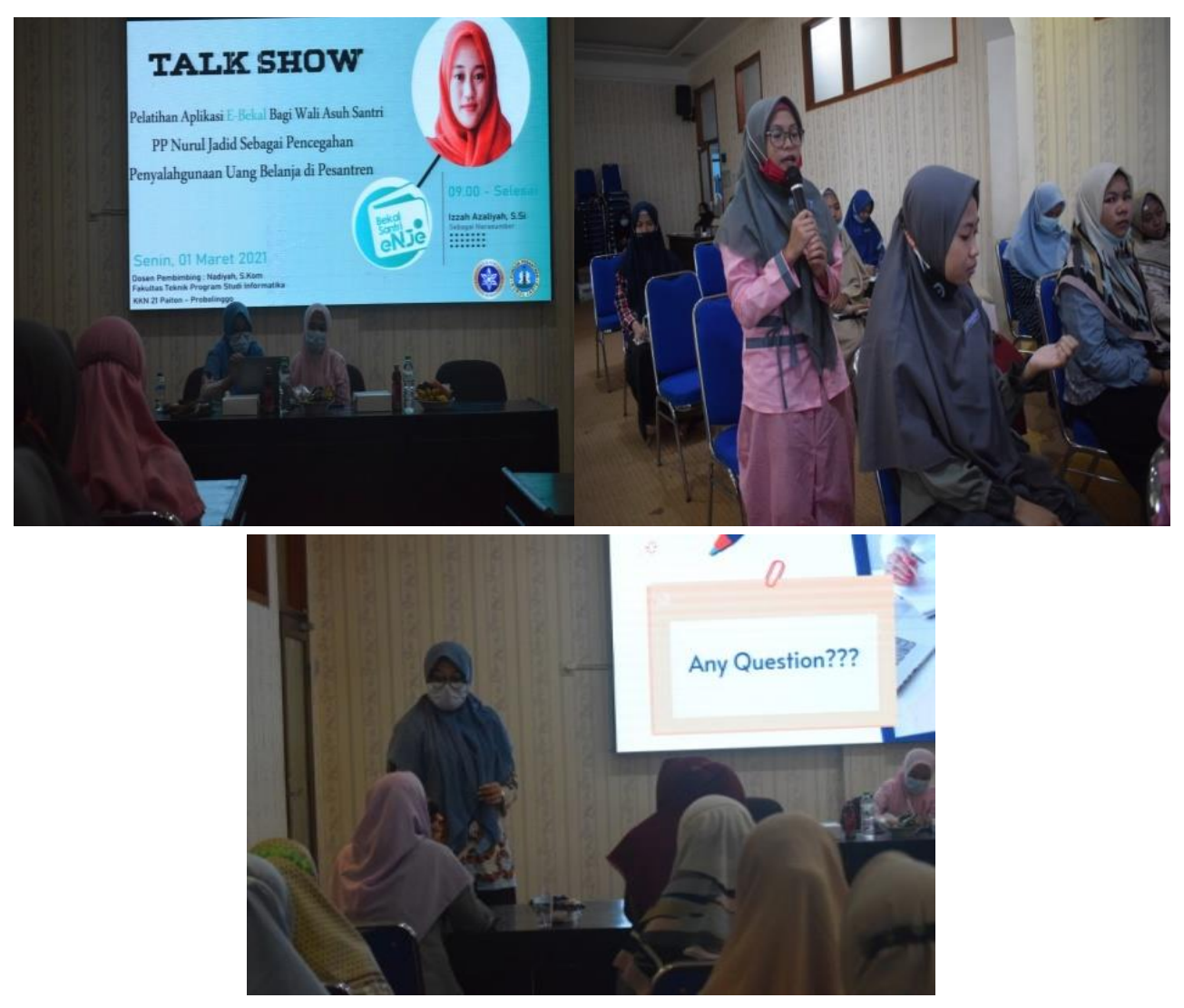

Gambar 1. Suasana Saat Pelatihan

Pelaksanaan program pelatihan ini mengusung konsep talkshow yang mengharapkan suasana menjadi tidak terlalu formal sehingga pesertapun tidak terlalu kaku dan ikut berperan aktif dalam pelatihan. Pengabdian kepada masyarakat ini menggunakan metode ceramah atau penyuluhan kepada semua peserta yang diisi oleh Izza Azaliyah, S.Si. Selain ceramah juga dilakukan sesi praktek tentang cara pemanfaatan E-Bekal bagi pengguna dan ditutup dengan sesi tanya jawab (diskusi). Perangkat yang digunakan yaitu video tron untuk penyampaikan materi yang disampaikan oleh narasumber.

Penyampaian materi dilakukan 2 tahap, tahap pertama penyampaian gambaran umum mengenai pemanfaatan teknologi Bekal Santri dalam Pondok Pesantren Nurul Jadid. Materi ini berisi mengenai berbagai masalah keuangan santri secara umum seperti seringnya kehilangan juga penyalahgunaan uang belanja santri dan memberikan solusi atas masalah tersebut dengan mengenalkan serta mempraktekan penggunaan fitur-fitur EBekal yang memanfaatkan pesatnya perkembangan teknologi 4.0 yang 
mengubah transaksi keuangan yang rumit dan invalid menjadi lebih cepat, mudah dan valid hingga penyalahgunaan dapat dicegah sebaik mungkin.

Tahap kedua yaitu sesi tanya jawab, moderator memberikan kesempatan maksimal 3 pertanyaan bagi peserta untuk menyampaikan berbagai pertanyaan tentang pemanfaatan E-Bekal Pondok Pesantren Nurul Jadid. Setelah 3 pertanyaan diutarakan segera penyaji menjelaskan jawaban dari berbagai pertanyaan tersebut dengan jelas, lugas dan baik yang sesuai dengan fakta-fakta yang ada sehingga dapat dipahami dan diterima oleh peserta.

\section{Hasil}

Setelah sesi pengisian materi yang telah dilakukan, maka dilakukan tahap selanjutnya yaitu evaluasi dan monitoring. Maka hal yang dapat kami lakukan untuk kedepannya yaitu mengadakan kegiatan serupa secara berkala agar bisa meningkatkan pengetahuan dan kemampuan pengguna tentang teknologi serta mendukung suksesnya layanan E-Bekal yang diharapkan membuat transaksi dalam pesantren menjadi cashless. Selain mengisi kegiatan pelatihan dengan memberikan pemaparan secara umum, tim pengabdian juga melakukan pembagian kuisioner yang berisi beberapa pertanyaan yang dapat digunakan untuk mengambil informasi singkat dari tingkat kepuasan penggunaan E-Bekal. Kegiatan pengabdian ini mendapat sambutan dengan baik oleh para peserta, terbukti dengan antusiasnya peserta selama kegiatan ini berlangsung.

\section{Pembahasan}

Berdasarkan kegiatan ini didapatlah beberapa hasil dan pembahasan seperti sebagai berikut:

a. Tampilan Fitur-fitur E-Bekal

1) Tampilan Awal Log In 


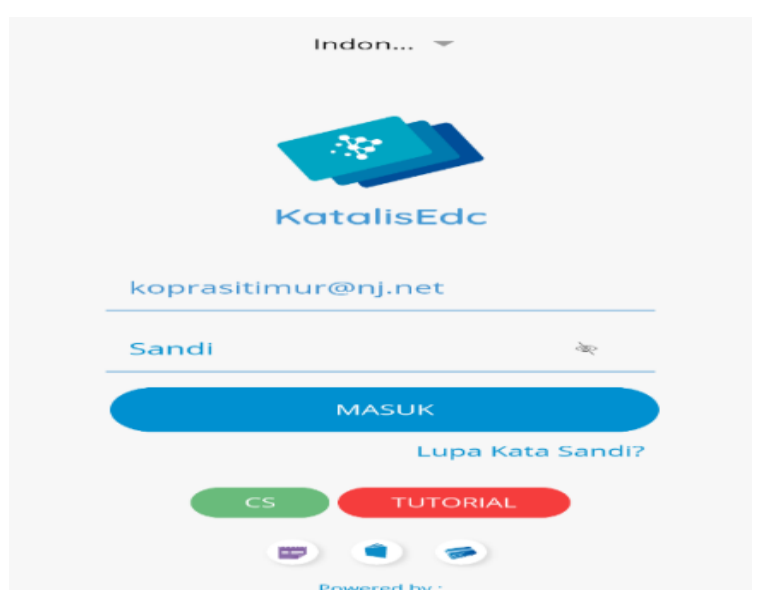

Gambar 2. Tampilan Awal Loh In

Tampilan ini merupakan tampilan awal ketika hendak mengoperasikan (log in) E-Bekal. Dengan menginput alamat email aktif dan kata sandi pengguna yang valid maka secara otomatis pengguna dapat menggunakannya. Jika tidak bisa log in meski user name dan kata sandi sesuai maka segera konfirmasi ke biro pelayanan E-Bekal.

2) Tampilan Profil Aplikasi

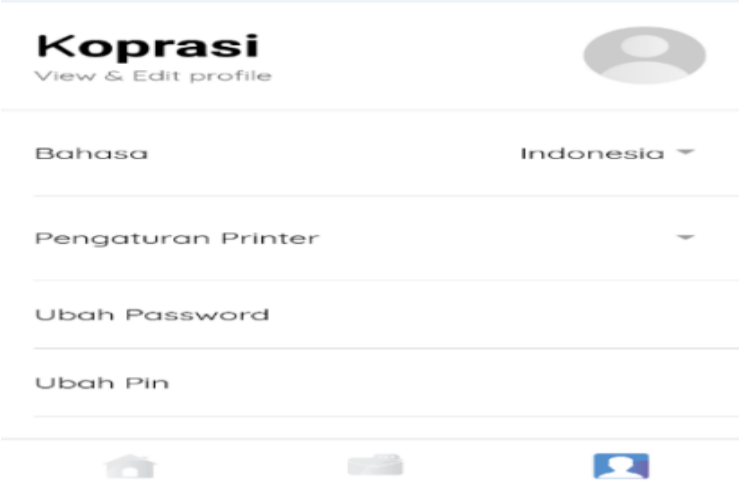

Gambar 3. Tampilan Profil Aplikasi

Tampilan ini merupakan tampilan koprasi-koprasi yang menggunakan EBekal yang didalamnya memuat pemilihan bahasa, pengaturan printer, ubah password dan ubah pin pengguna.

b. Tampilan Home

1) Internet Hidup 


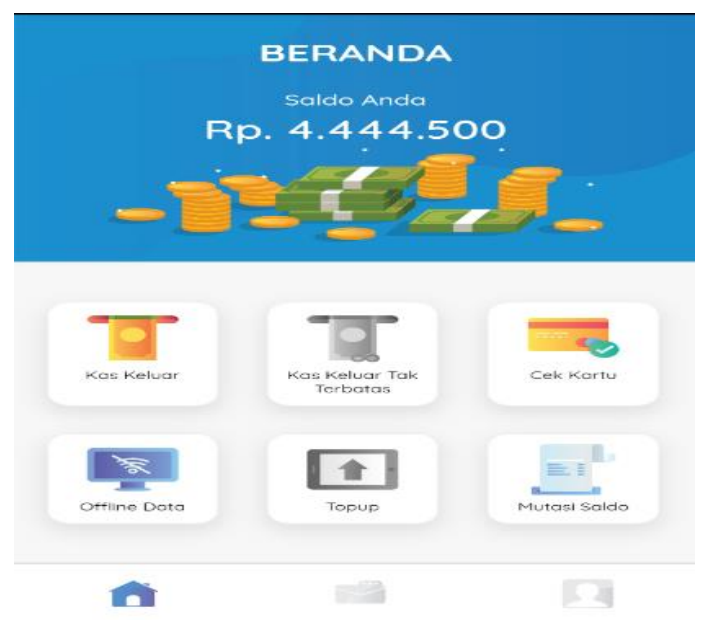

Gambar 4. Tampilan Internet Hidup

Tampilan di atas merupakan tampilan home jika terkoneksi internet, jika internet aktif, menunya ada di bagian listrik hidup, jadi ada kas keluar, cek kartu ofline data, top up dan mengisi saldo.

2) Internet Mati

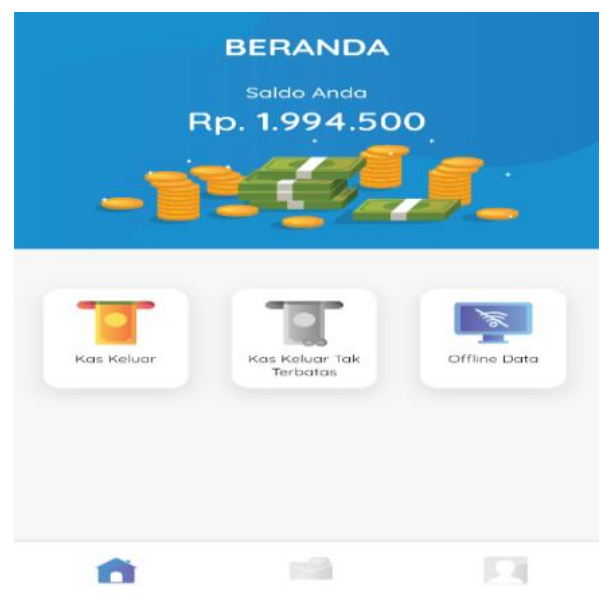

Gambar 5. Tampilan Internet Mati

Jika offline data/ tidak ada jaringan internet tetap menggunakan kas keluar hanya saja tidak akan masuk ke mutase saldo tapi akan masuk ke offline data yang kemudian ketika jaringan internet sudah menyala, offline data nantinya di isi agar saldonya masuk ke saldo penjual hingga yang muncul di tampilan home hanya kas keluar dan offline data.

c. Kas Keluar 


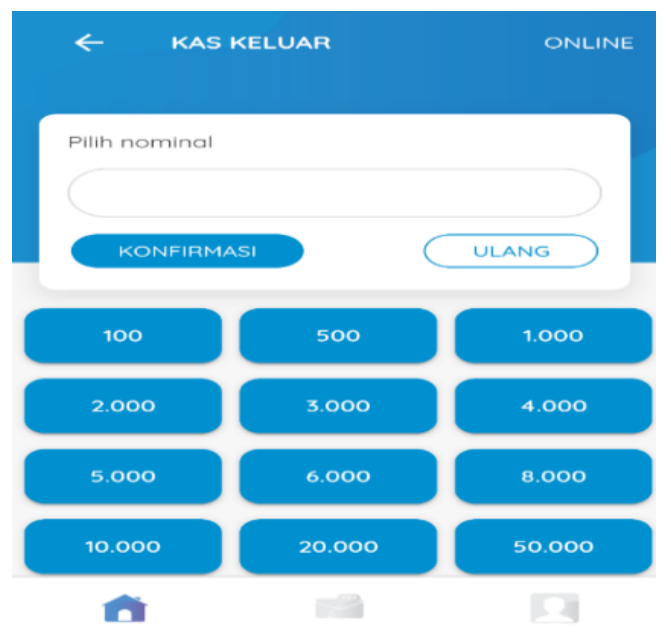

Gambar 6. Tampilan Kas Keluar

Fungsi dari tampilan ini yaitu untuk memasukkan nominal transaksi yang akan dikeluarkan (dibayar).

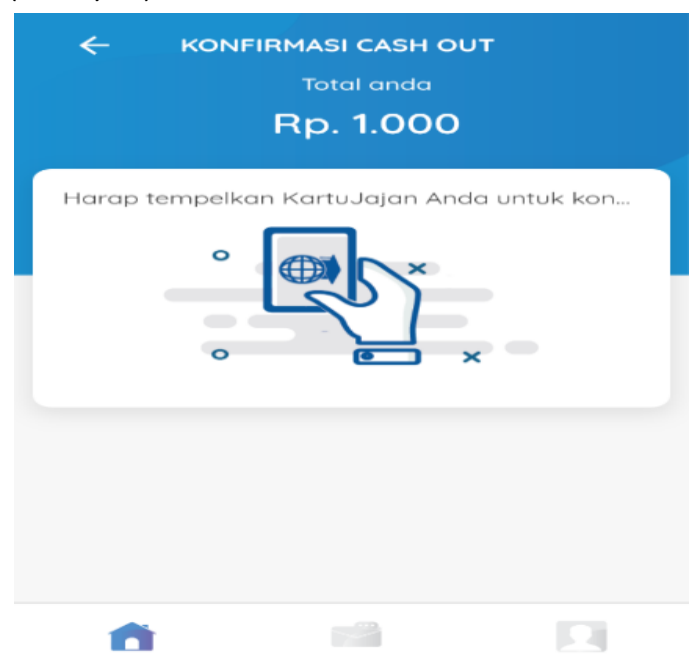

Gambar 7. Tampilan Memasukkan Nominal Transaksi yang Akan Dikeluarkan (Dibayar)

Setelah klik tombol konfirmasi maka scan bagian kartu pada tampilan diatas untuk melakukan konfirmasi transaksi dengan cara menempelkan kartu E-Bekal. 


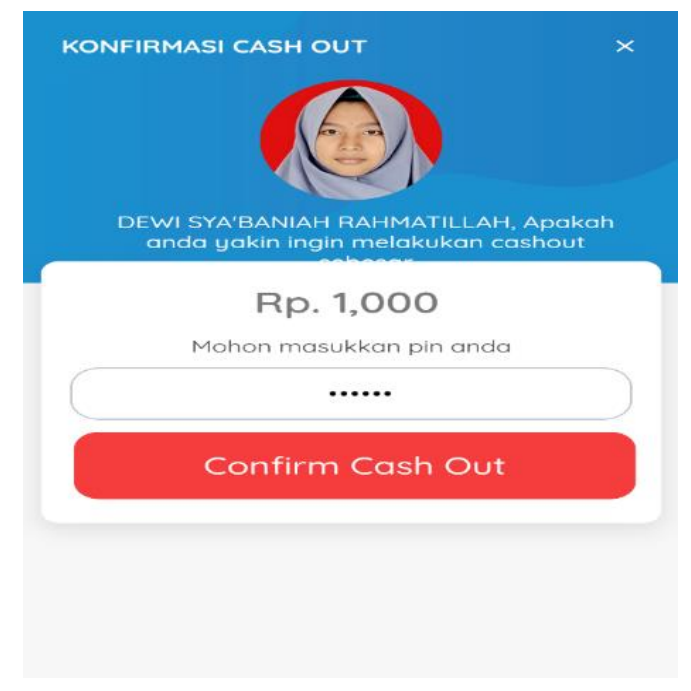

Gambar 8. Tampilan Konfirmasi Transaksi (Dibayar)

Jika tahap pada point diatas selesai maka aplikasi akan melakukan konfirmasi kembali dengan memasukkan pin pengguna kartu untuk memastikan transaksi yang akan dibayarkan.

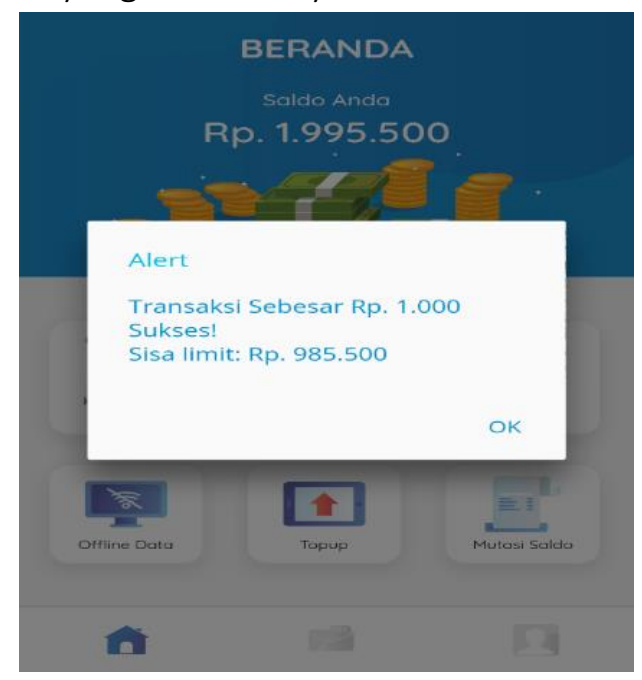

Gambar 9. Tampilan Konfirmasi Selesai Transaksi (Dibayar)

Setelah semua proses berhasil maka akan muncul notifikasi bahwa transaksi sukses seperti tampilan diatas.

d. Cek Kartu 


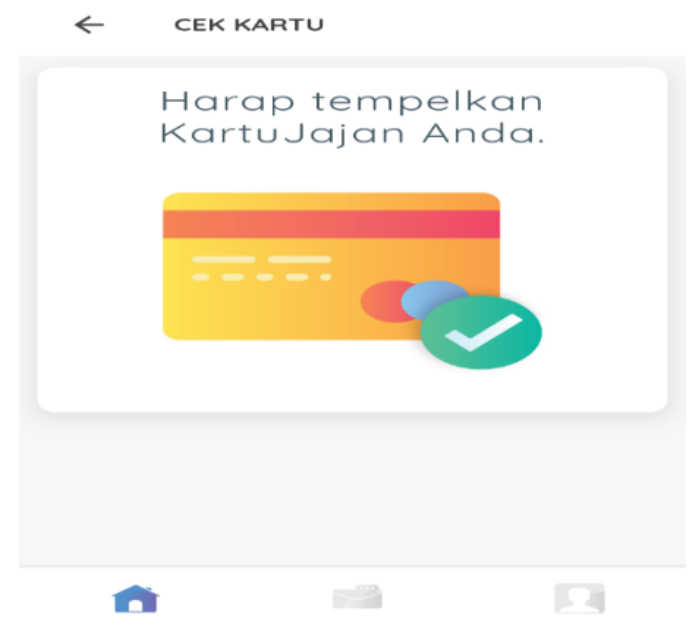

Gambar 10. Tampilan Kartu

Fitur di atas digunakan untuk melihat sisa saldo yang dimiliki pengguna. Caranya dengan menempelkan (scan) kartu pada tampilan diatas hingga muncul tampilan seperti dibawah ini:

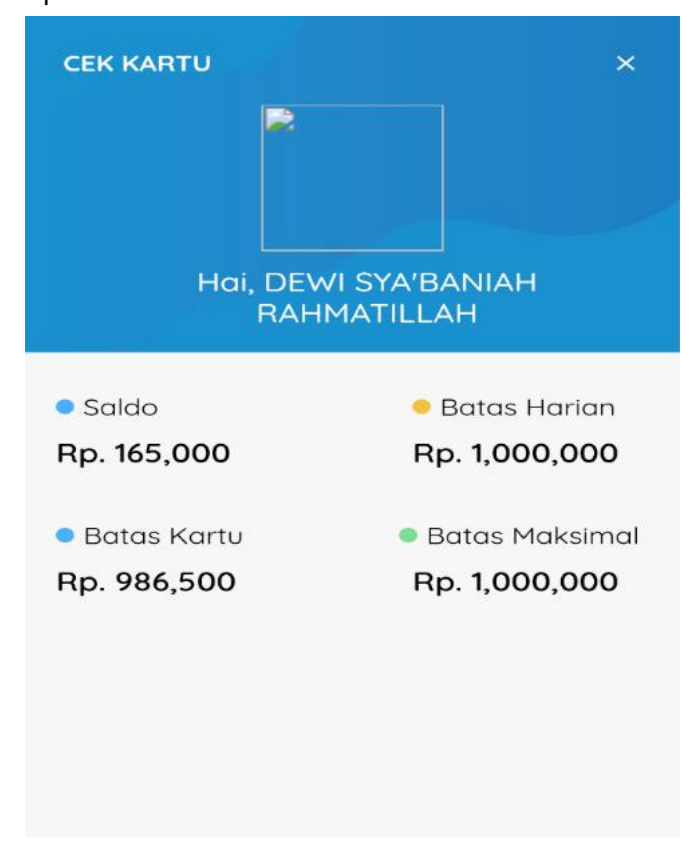

Gambar 11. Tampilan Kartu untuk Mahasiswa 


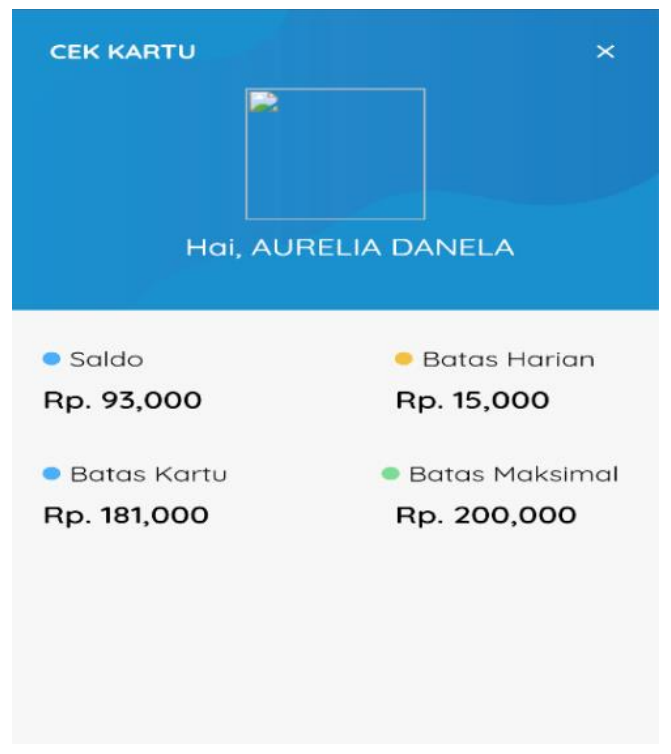

Gambar 12. Tampilan Kartu untuk Santri

Ada bermacam tampilan pada proses ini, ketika pengguna berstatus mahasiswi maka batas hariannya 1 juta karena di khawatirkan untuk membeli sesuatu anak asuhnya dan keperluan kampus, sedangkan siswi batas hariannya itu sekitar Rp.5000-Rp.25.000 tergantung keinginan orang tua.batas maksimal pembelanjaan yang bisa di belanjakan meskipun unlimitide tapi maksimal sekitar 1 juta, kemudian untuk batas harian yaitu hasil akumulasi saldo yang di gunakan secara penuh.

e. Offline data

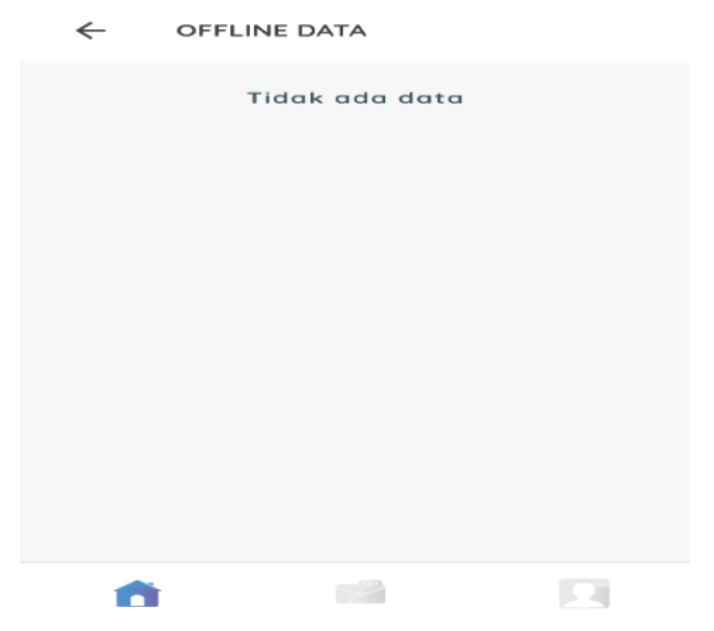

Gambar 13. Data Offline 
Memuat transaksi yang terjadi saat offline. Dalam Offline data semuanya sudah disetting atau memang marcentnya tidak pernah menggunakan offline data.

\section{f. Mutasi saldo}

Tampilan ini berfungsi untuk melihat riwayat transaksi yang memuat histori data pembelian dan jumlah nominalnya. Mutasi saldo nilai transaksi memuat tentang barang apa saja yang dijual dalam sehari dan saldo masuk. Awalnya saldo berupa uang digital ketika case out uang digital itu akan di jadikan uang cash, pengambilannya bisa dilakukan di kantor E-Bekal. Untuk pembiayaan top up ada dua macam yaitu, top up via bank BNI terkena potongan Rp.3000, selain di bank BNI ada potongan Rp.3000 dan Rp.6.500 sebagai biaya admin, dan semisal di Nurul Jadid, bisa di NJ Mart, kantor EBekal wilayah,terkena potongan Rp.2000, untuk biaya per bulan ada biaya applikasi sebesar Rp.1000, biasanya di jadikan satu dengan kos makan, kemudian ada biaya ganti kartu, ketika karu hilang akan di gantikan dengan katru putih, tapi semisal sudah di buatkan kartu baru ada biaya sebesar Rp.25.000.

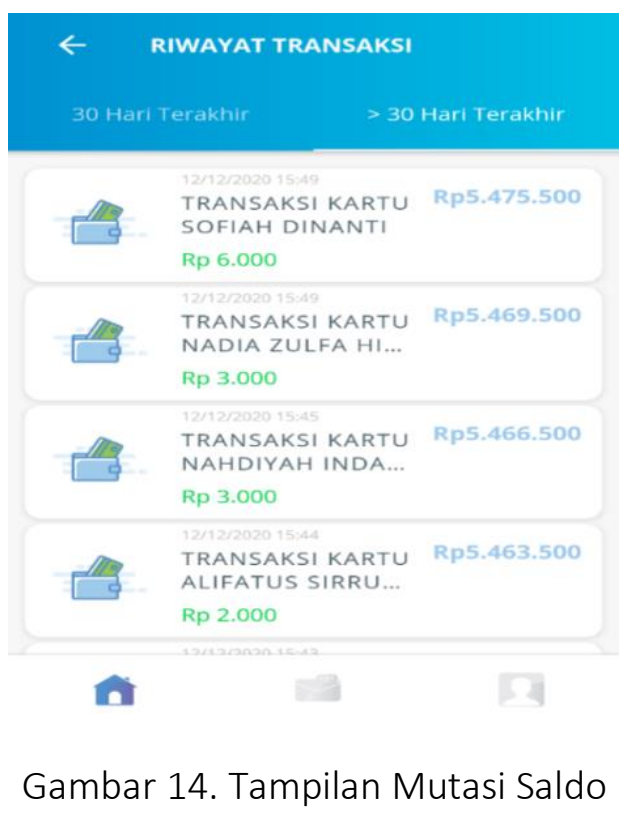


g. Kotak Masuk

Tampilan ini memuat pemberitahuan setiap melakukan cash out serta jumlah nominal yang digunakan.

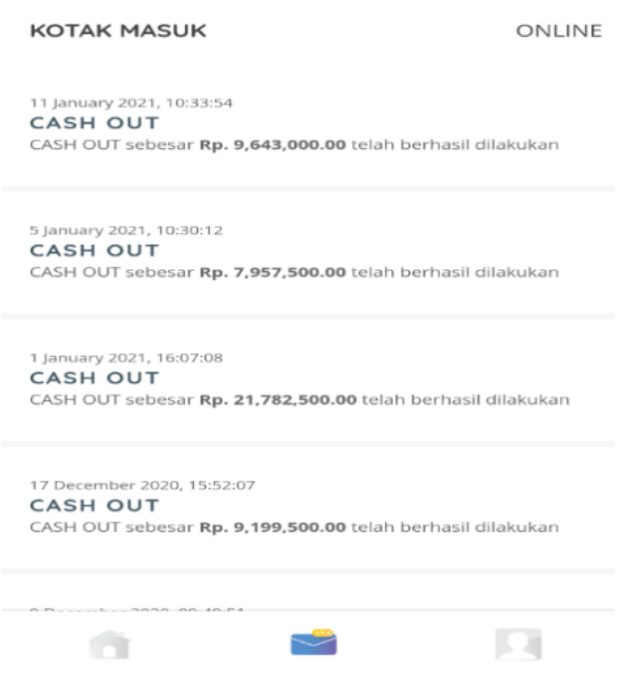

Gambar 15. Tampilan Kotak Masuk

\section{Kesimpulan}

Pandemi Covid-19 menimbulkan banyak dampak dalam berbagai aspek kehidupan salah satunya dalam aspek pendidikan bukan hanya di Indonesia melainkan seluruh dunia. Maka dari itu untuk menghadapi kondisi ini, Pondok Pesantren Nurul Jadid mengeluarkan suatu sistem yang kenal dengan E-Bekal. E-Bekal merupakan aplikasi mobile untuk mempermudah wali santri Pondok Pesantren Nurul Jadid dalam melakukan pembayaran kos makan santri, pengiriman bekal belanja harian santri, sehingga santri langsung dapat melakukan transaksi secara non tunai di area Pondok Pesantren Nurul Jadid.

Kegiatan sudah terlaksana dengan baik namun masih ada kekekurangan yang perlu diperbaiki kedepannya. Hal yang menjadi kekurangan kegiatan ini adalah belum bisa memfasilitasi para peserta dengan perangkat gadget dengan spesifikasi tinggi dan belum bisa menyediakan jaringan internet dengan kecepatan yang maksimal dan rata untuk para peserta. Mereka masih menggunakan fasilitas jaringan wifi pesantren yang mana dalam hal ini memiliki kecepatan yang relative rendah sehingga butuh share tethering ke rekan lainnya. Harapan kedepannya semoga dapat mengadakan kegiatan pelatihan dengan fasilitas yang lebih baik. 


\section{Pengakuan}

Ucapan terima kasih kami sampaikan kepada lembaga Universitas Nurul Jadid yang memberikan fasilitas untuk menyelesaikan jurnal ini dengan judul "Pelatihan Aplikasi E-Bekal bagi Wali Asuh Santri PP. Nurul Jadid sebagai Upaya Pencegahan Penyalahgunaan Uang Belanja Santri di Pesantren."

\section{Referensi}

Fitri, S. (2020). Pelatihan Pengelolaan E-Commerce pada Yayasan Pondok Pesantren Al-Hikmah Mangunreja Kabupaten Tasikmalaya . Jurnal Pengabdian Kepada Masyarakat, 273-279.

Irawan, E. (2019). Digitalisasi Madrasah di Era Revolusi Industri 4.0: Refleksi Kegiatan Pengabdian Kepada Masyarakat di Kabupaten Ponorogo. Jurnal Pengabdian kepada Masyarakat, 160-168.

Jadid, P. P. (2020, Oktober 31). Kartu E-Bekal NJ Sebagai Akses Pelayanan Santri di Pondok Pesantren Nurul Jadid. 14 Februari 2021, p. 1.

Siahaan, M. (2020). Dampak Pandemi Covid-19 Terhadap Dunia Pendidikan. Jurnal Kajian Ilmiah, 1-3.

Syafiih, M. (2020). PKM Peningkatan Keahlian Ibu PKK di Desa Karanganyar dengan Memanfaatkan Sumber Daya Alam (SDA) melalui Olahan Abon Ikan Laut dan Nugget. GUYUB: Journal of Community Engagement, 90-102.

Syafina, I. (2021). E-Bekal. Probolinggo.

Syafina, I. (2021). Fitur E-Bekal. Probolinggo.

Syafina, I. (2021). Latar Belakang E-Bekal. Probolinggo.

Wanto, A. (2018). Pelatihan dan Bimbingan dalam Pemanfaatan Internet yang Baik dan Aman bagi Pelajar SMK Anak Bangsa Desa Bandar Siantar Kabupaten Simalungun. Jurnal Pengabdian Kepada Masyarakat, 149157.

Zayyadi, M. (2020). E-Santri Sebagai Aplikasi Pembelanjaan dan Pembayaran Mandiri oleh Santri di Pondok Pesantren Az Zubair. Jurnal Solusi Masyarakat, 300-307. 